\title{
Progresive Tax Vs Flat Tax and Its Effects on the Foreing Direct Investments in Albania
}

\author{
Dr. Orkida llollari \\ European University of Tirana \\ orkida.ilollari@uet.edu.al \\ Prof. Assoc. Dr. Ermela Kripa \\ European University of Tirana \\ ermela.kripa@uet.edu.al
}

Doi:10.5901/ajis.2016.v5n3p79

\begin{abstract}
The inspired for the treatment of this topic is the debate regarding the effect of the two tax systems, flat and the proportional one that has been adopted in our country last two years. The impact of taxes is not only important in the economic side but they have their influence and in social side. The major competition between the countries and the compaction to attract foreign direct investments is the tax system itself with major economic and competition among countries to attract foreign direct investment is itself the country's tax system. The most important factors affecting the state budget income, are income tax and personal income tax business. The goal this study is to analyze the effects that the change on the tax system has had on the impact on the income tax rates in Albania. For this reason will be analyzed the effects of income tax on inflows of foreign direct investment, creating a clearer idea of how these two models are been adapted into a taxation economic situation in Albania during their application. Studying and deal with the experience of both, tax systems will be understood the importance of change that has a country's tax system on foreign direct investment. The research question raised in this study is: how and if the changes in the tax system, has impacted foreign direct investment? Methodology: Literature review of the tax systems, analysis of the factors influencing the tax income and a linear singular regression through the empirical measurement
\end{abstract}

Keywords: Tax proportional, Flat Tax, Personal income tax (PIT), foreign direct investment (FDI)

\section{The Review of Taxing Literature}

The basics of proportional taxing were first proposed by two American proffesors Robert Hall and Albin Rabuschka in 1981. Briefly proportional taxing includes the application of a taxing system which operates in a single taxing level. The flat tax is set supposing that the revenues are once taxed during their turnover and that's when they are possessed by the individual. Low taxes limit the opportunity of expanding the government's role, they limit the public service spectre and at the worst case scenario they reduce the quality of these services. Due to the beforementioned reasons Hall and Rabuschka explained that the system which was being used at that time had two problems that could be resolved implementing the flat tax. Firstly that system was very complicated. The second problem were the high marginal norms of taxing, which meant that the taxing norms were increased with the increase of the revenues. Progressive taxing according to Adam Smith is related to the ability of the individual to pay more when he earns more. This type of taxing is applied in higher rates in higher revenues compared to the lower ones. The purpose of progressive taxing is to tax more but at the same time to offer more public services and guarantees, education, health services, infrastructure, entertainment etc,. The supporters of flat taxing say that this taxing system triggers the economical growth in the country, because it demotivates the tax evasion since individuals and businesses will have less opportunity to evade the tax payment. In the other hand the supporters of the progressive taxing think that the economy will perform better in this system. The key argument against the proportional taxing is the negative effect it has on the redistribution of the revenues, a vast difference is created in the national redistribution of the revenues. The pros have started since the creation of this system when Adam Smith supported the idea of "payment ability". One of the economists of the Great Depression, John Maynard Keynes says that higher taxing rates to the rich gives more opportunity of consume to the poor. According to the neo-marksist theory preventing the accumulation of the capital using the progressive system will also prevent great crisis as the latest financial one was. The strongest cons to the progressive system argue that this system stimulates the tax evasion and the attempts to evade the liabilities and so to decrease the taxed revenues. 


\section{The Taxing System in Albania, Analysing the Flat System Period, the Effect of PIT in the Budget Income}

In Albania with the application of the proportional system the norms of taxing on earning, while with the application of progressive system the norms of taxing on earnings were increased making the the taxing system part of public discussion on politics circles and the financial experts. Taxing on incomes in Albania is regulated with the law nr.8438 on 28.12.1998 "Income taxes"changed with the Directive of the Ministry of Finances nr. 5 on 30.01.2006 "Income taxes".In Albania between years 2008 and 2013 has been used the flat taxing and in 2014 until now is used the progressive taxing. The total income in the government budget consists of all the incomes from different taxing sources, non-taxing incomes and aids given from the governments of other contries and donners. The budget incomes are presented as increasing year after year, excepting the two last years that we have an annual decrease of $0.5 \%$ of these incomes. The taxing incomes are the main source to cover government expenses. In 2013 was the highest value of Taxing Revenue collected during these years, which was 303.92 billion leke. The revenues taken from the aids vary a lot during these years. In 2010 was the peak of revenues collected in 31.55 billion leke, while in 2005 was the lowest point in 14.178 bilion leke.

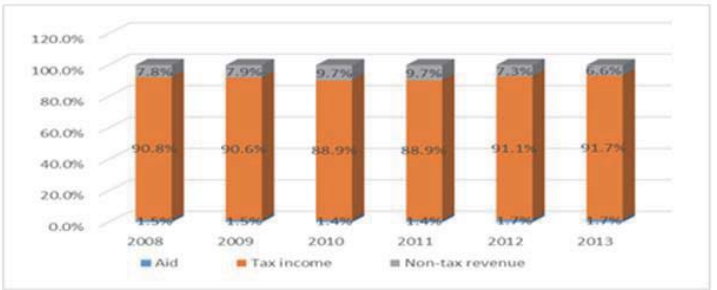

Graph. Nr 1. The structure of budget revenues as percentage to total budget (2008-2013) Resorce: Ministry of Finance

The taxing income are the main source in the buget income and as such it represents special interest. The average rate of these income during these years reaches about $88 \%$ of the total income. As seen above the heighest rate has been in 2013 with a value of $91.7 \%$. In order to mention the other two groups which make up the government budget we see an increasing trend during the years of aids, especially in 2013 with 1.7\%. Meanwhile the nontaxing incomes from 2008 to 2011 have had positive considerable increase, but after 2011 we see only decrease of these numbers. The taxing incomes are divided in three main groups, which are incomes from taxing and the customs, incomes from local government and incomes from special funds. It is needed to understand the importance of some special sources of taxing in the total incomes. We will study only the income group of taxing and customs since there is included also the taking group we are studying, taxing on the personal income.

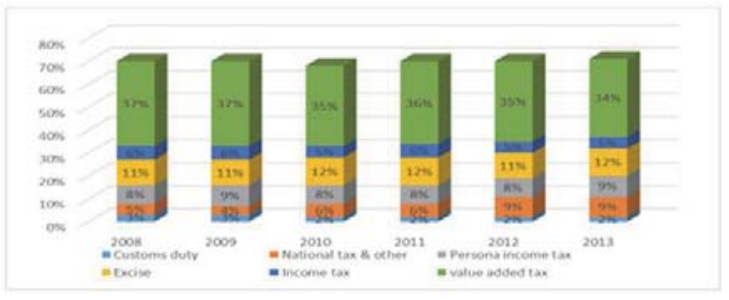

Graph. Nr 2. Income from taxes and customs duty on the total of budget 2008-2013 Resorce: Ministry of Finance

Revenues from taxing and customs are revenues which are collected by all types of taxes that apply by the Central Government. As we can see the main source in this category toward the total budge is VAT, excise and the personal income tax. Tax over personal revenue seems to be the source with steady continues growth. Incomes from PIT in 2013 marked their highest value by $9 \%$ in the national budget. We will take a look to values collected by PIT according to revenues. These separations are made for revenues from wages of public sector, wages of private sector, banking interests, dividends, real estate transfers and revenues from other voices. During the surveyed years, PIT has a growing 
trend as we said above. The main weight of PIT values structure is revenue by wage taxing, which makes up an average of $60 \%$ of PIT according to studied years.

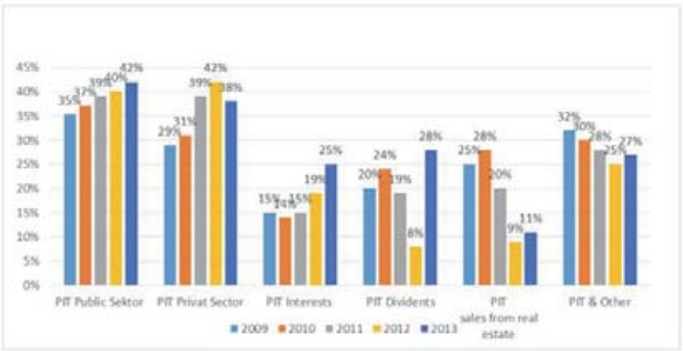

Graph. Nr 3. PIT as per source of revenue 2009-2013

Resorce: Ministry of Finance

Revenues that comes from personal income taxes in public and private sector have the same trend. Small business entities that have an annual circulate of 2-8 million Leke have paid a total of 172 million Leke for the personal incomes from January 2013 to November 2013, compared to 135 Million Leke of last year or 27\% more. As we can see wages income taxing in public sector are increased every year, presenting a positive growth. While wages ncome taxing from private sector are increased every year because of wages increasing, 9nly in 2013 there is a decrease of these revenues. This is due to:

- Reducing in number of taxpaying entities with $6.6 \%$ compared to 2013 or 1,803 unit;

- Decreasing in wages declaration (following the abilition at the end of 2012 of refereal wages);

- Increasing in threshold of exclusion from PIT for wages, from 10000 to 30000 Leke (valued effect of this change which started to apply in the middle of 2013 was about 1.4 billion Leke for all wages.

PIT from interests of deposits and investments in bonds is increased from 2009-2013, because of bank deposits interests which make up $98.5 \%$ of budget.

\subsection{Analysis of progressive taxing period and effect of PIT in budget revenues}

Progressive taxing has being applied in January of 2014, that is why this analysis consists for two years 2014-2015. But to make a comparison with flat taxing we will study years 2012-2013 too. The progressive taxing is separated in three levels. For employees with wages up to level of 30000 leke there is a TIP at the value of $0 \%$. For revenues from 30.001 130.000 leke the tax rate is $13 \%$. And for revenues higher than 130.000 leke the tax rate will be $23 \%$. The budget incomes have had a decrease trend in 2012-2013. But this indicator is improved a lot during 2014, where budget incomes reached a total of 366.7 billion leke, with an increase of 12\% compared to 2013. 2014 represents the year with the most collected revenues in the countrie's budget. While the forecast for 2015 for the budget income was 414.5 billion leke, hence the increase would be $13 \%$ compared to 2014. Actually this didn't happen because the budget income was 381.1 billions, about 33.4 billion leke less.

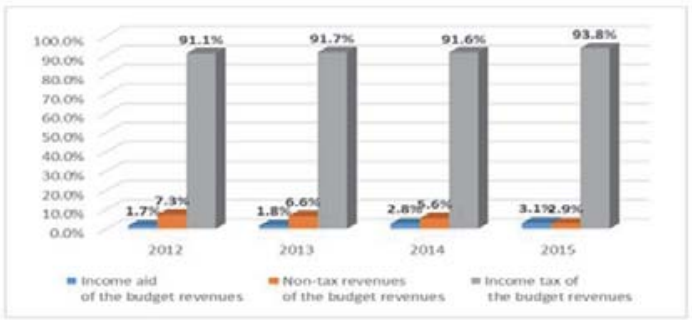

Graph. Nr 4. The structure of budget revenues as percentages of the total budget

Source: Ministry of Finance 
The structure of the budget income in 2014 doesn't show heavy fluctuation compared with the other years. As you can see in the above chart the taxing income takes the main role in the country's budget, as in the time frame 2008-2013, but compared with this period we can see that taxing revenues have had the heighest role in 2015.

Thus we see that tax revenue has been increased from year to year. While aid revenues have increased throughout time period 2008-2013 continuing in 2014 and 2015 respectively 2.8 and $3.1 \%$. As regards at non tax revenues they occount a weight of about $5.6 \%$ in 2014 and $2.9 \%$ in year 2015 to total budgeted revenues. This item has decreased from 2014 to 2015 and it was due to the decrease of profit transferred by the Bank of Albania in the state budget. To understand the weight that some specific items have on tax revenues, see the table below. We will examine only the item of revenue from taxes and customs. Once there is also the item we are interested such as personal income tax.

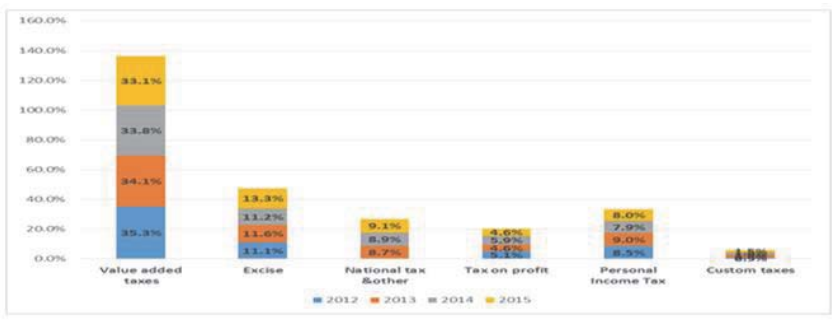

Graph. Nr 5. The ratio of income from taxes and customs to the total budget 2012-2015

Source: Directorate of General of Taxes

As claimed above income and customs tax is one of the component voices of taxes. This item includes 6 main categories: Value added tax, income tax, excise tax, personal income tax, national tax and customs duty. In 2014, 86\% of revenues are attributable to revenue from taxes and customs and social insurance income. As we see, in this period, the highest share of budgeted income are occupied by value added tax, excise and personal income tax. But it is observed a decline in the share of value added tax, from 2012-2013, in 2014-2015. The weight of personal income tax from the chart above shows that by 2013 the share of this tax to the state budget was growing but after this year they declines. A small difference between the years 2014-2015 is that the increase in 2015 as mentioned above, comes from the intrest rate tax, dividends, royalties and rents increased by $10 \%$ to $15 \%$.

To understand this decrease we will see the TAP values collected by income source. By studying the voices of personal income tax we will see which of them has had an impact on reducing the weight of the TAP on the state budget.

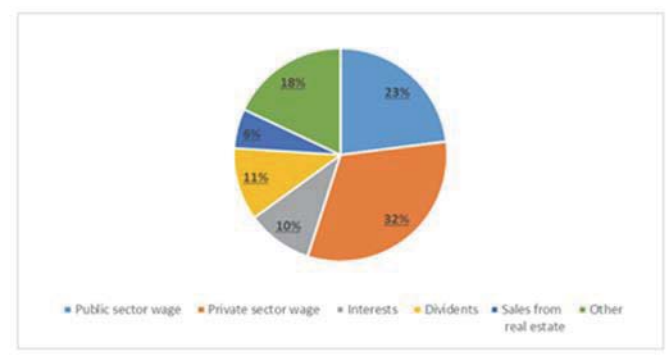

Graph. Nr 6. Personal Income Tax date from 2014

Source: Ministry of Finance

As shown in the graph above in 2014 the highest share in the personal income tax is occupied by the voice of the private sector wage followed by the public sector. But compared with 2013 performance tax on wages in the public sector is negative, which has declined from 29.4. Also negative is the performance of tax wages in the private sector, which has suffered a decline of 11.7 percent compared with a year ago because the number of taxpaying entities decreased by 12.073 unit. Also not true declaration of salary of the employers, declaring less and the rest of the income is declared as 
bonuses or various rewards that are not taxed. Also, the high costs of calculating personal income tax have reduced the revenue collected from this tax. These are the causes of decline in the share of personal income tax to the state budget.

Interest income on deposits and investment in bonds has declined in 2014 compared to 2013 with a 22.1 percent rate. Mainly from interest on bank deposits, which account for about 88.5 percent of the total, while interest income treasury bonds accounted for only 11.5 percent of the total, where a year ago these were exactly $98.5 \%$ interest income banks and interest income of treasury bonds were 1.5\%. Income from dividends has increased by 25 percent compared with a year ago. Tax on sale of immovable property (individuals) has increased by 183 percent compared with a year ago.

\subsection{The impact of income tax on inflows of foreign direct investment in 2008-2013}

Taxes are recognized as an important factor for entrepreneurs deciding where to invest, but the experiences within and abroad it is not the sole determining factor. Foreign investments from best practices are drawn from sites that offer profit opportunities, transparency and predictable and non-discriminatory legislation, legal and regulatory system in investment protection. Different countries vary fiscal policy to attract foreign investors in bringing economic growth. Therefore, in Albania in 2008, there was change of fiscal policy by lowering taxes as a way to create competition with other countries to attract investors. With the introduction of flat income tax the income changed from business, such as profit tax. This rate of profit tax was reduced from $20 \%$ to $10 \%$. There are other reasons as regards the application of the flat tax in Albania, but the two most important ones mentioned above are:

- Application of the flat tax to reduce informality in the labor market in Albania;

- Application of the flat tax to be consistent with the regional tax policies to attract foreign investors;

Supporters of lower tax rates on personal income, but also income tax base their argument on the competition between neighboring countries in the contest of attracting as much foreign investment. In Albania personal income tax and profit tax rate were $10 \%$ in the period 2008-2013. Weight of Albania as host country in foreign direct investment in the region of Southeastern Europe has increased since 2007. While the countries of Southeast Europe and the rest of the world is suffering decrease. This was the result of the recent financial crisis. In 2010 figures show higher inflows that Albania has had in its history, while the rest of these countries in foreign direct investments were suffering significant decline.

In the chart below we will see the performance of foreign investment inflows in Albania for the years 2008-2013:

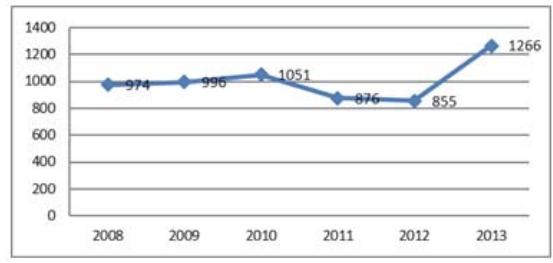

Graph 7. FDI inflows in Albania 2008-2013

Source: UNCTAD, World Investment Report 2014, Bank of Albania

In 2009 do not see any great difference; it is almost insignificant in comparison with 2008.

In 2010 there was an increase of foreign direct investments with a growth of $6 \%$ compared with a year ago. During the period 2011-2012 there has been reduction in foreign direct investment, this because foreign investment evidence corruption and the implementation of a favoritism tax rules in special cases. This is also one of the factors which prevent the competitiveness with other countries. Then we have a significant increase in direct foreign investments.

\subsection{The impact of income tax on inflows of foreign direct investment in 2012-2015}

Progressive taxation in Albania consisted on growth rates of personal income tax and corporate tax. As a result of this growth, especially in the income tax rate will have a negative impact on foreign direct investment. Investment in our country has been decreasing over the years. Reports of the World Bank and other international economic institutions estimate that our economy has maintained an upward trend, but it can not be said for foreign investment. One of the causes of the decline of foreign direct investments has been the rising costs for foreign companies. As claimed in the 
table we can see that the inflow of foreign direct investments in Albania have decreased from 2013 to 2014. Experts believe that this result has come as a result of tax increases in 2014. ${ }^{1}$

\subsection{Regression analysis}

To understand whether foreign investors are influenced by the tax we have realize a regression analysis. In this analysis, we have taken two variables, income tax and investment. See the chart below to understand the connection between income tax and foreign direct investment inflows.

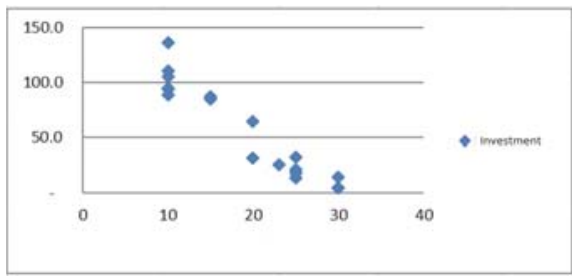

Graph 8: Graphical presentation between the rates of income tax and FDI

What can be seen from this graph is that with the increase of the tax rate we have a significant decline in foreign direct investment, and with the decrease of the income tax rates we observe an increase in foreign investment.To prove how strong is this correlation was used the regression analysis. To view the reliability of the results of this analysis, we will verify if its assumptions are met, namely: the distribution of residuals should be normal.

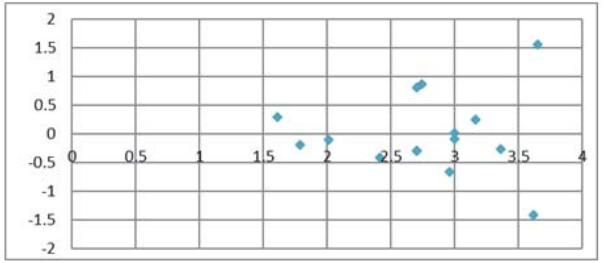

Graph. Nr 9. The dependence of standardized residuals provided by standardized values

According to the above graph, it is observed that the distribution of residuals is normal because is not affected the normal distribution of residuals. Thus fulfilled the first condition.

1. The average of this distribution should be near or equal to 0 . After the residual results tabulated their average value resultes near 0 .

2. Distributions must have a constant standard deviation for each independent variable value.

3. Since standard deviation average is close to 0 is verified resulted in a condition 3.

4. Observations should be independent.

The number of observations turns out to be 15 , who were randomly selected by a T-student distribution. Once we noticed that the above assumptions are met, we will study now the regression results.

This analysis is as follows:

Table Nr 1. The relationship between the rate of income tax and foreign direct investment

\begin{tabular}{|c|c|c|c|c|c|}
\hline Model & $\mathrm{R}$ & $\mathrm{R}^{2}$ & $\mathrm{R}^{2}$ adjusted & Standard deviation & Observation \\
\hline 1 & -0.953 & 0.914 & 0.909 & 130.7 & 15 \\
\hline
\end{tabular}


The table above provides information on the coefficient determination that is (square R) 0.914 and standard error of assessment is respectively 130.7, these coefficient shows a kindly approach observed with the line values on the estimated regression. Value of $R$ square is around 1 , and according to this result say that we have a high degree of convergence between the two variables in our case the income tax and foreign direct investment. Also we have the correlation coefficient $(R)$ between two variables which is -0.953 which shows strong linear connection between variables in the opposite direction. But to confirm how tax have impact on foreign direct investment we will see the results of the questionnaire made from AIDA Agency under the guidance of UNCTAD and in close cooperation with the Association of Foreign Investors in Albania (FIAA) and UNDP. ${ }^{2}$ On the survey, were involved 60 firms with foreign capital construction, which was interviewed for a given perception, based on the experience gained of the business environment and to look the way how different factors affect the activity and plans of the company? The main determinants that influence the decisions of firms will be divided into three main categories: financial and human capital, legal aspects and investment environment.

The treatment in like manner made us realize the expectations that foreign firms before investing, the experience they earn when investing and their plans for improvement and expansion in the coming years The main determinants of legal aspects are: clarity, and fairness of laws and regulations, judicial legal system and commercial functioning, economic and political stability, lack of corruption, tax system, low levels of bureaucracy inspections and trade and customs regulations.

\section{Conclusions and Recommendations}

Direct taxes in the region and Albania, represents the competitive tax field between them. A special importance occupy direct taxes on personal income tax from salary. These countries try to have lower rates taxes to attract foreign direct investment. Personal income tax on proportion occupied on tax revenues and state budget during the flat tax has increased greatly, it is observed more in 2009 and 2013.

After the implementation of progressive tax has been verified a decrease of personal income tax from 2014 as well as tax revenues and the state budget, while revenues collected from income tax on corporate income increased in 20142015. In terms of weight they have in tax revenues because the tax rate in this period has increased from $10 \%$ to $15 \%$.

In the period of the flat tax, on growth of personal income tax has influenced the public sector wage that has had a significant increased year-on-year. This growth has affected the growth of wages in half of 2013.

On the performance of revenues from private sector, has contributed the increase of wages, but then in 2013 this growth has been slowing down due to the reduction in the number of tax payers, reduction of declarations and rising wage exemption threshold for salaries of 10.000-30.000 TAP ALL.

One reason for the implementation of proportional tax in Albania on income tax with lower rates is linked with the aim to attract foreign investors. One of the scope of this study is the identification of the impact of the reduction of tax rates on profit of foreign direct investments in Albania. This hypothesis is confirmed by the results of the regression analysis taken in this stud, which show a strong inverse relation between income tax rates and foreign direct investment flows.

Foreign investors come in Albania because of the advantage of low rates of taxes on profits of companies, but there are other determinants important investment decisions, as claimed are political and legal stability, property rights, infrastructure, environmental standards ect.

What is noticed in the study by regression analysis is that increasing tax rates on profits, it leads to falling inflows of foreign direct investment and also to decrease the income tax have increased inflows of foreign direct investment.

\section{References}

Blankson, Samuel. A brief history of taxation. (2007) fq6

Cikël leksionesh Taksim

Civici, Adrian. Opinion: Dilema e vështirë taksë e sheshtë apo progresive. (Mars 2013)

Hall, Robert \& Rabuschka, Alvin.The flat tax. (1995). Hoover Institution Press Publication No 423

Kaci, Mimoza. Doktoratura "Efektet e konkurencës tatimore mbi normat e tatimit mbi fitimin në Shqipëri" (2014)

Keynes, M John, Critical assessment, Second series. (2002). Edited Wood, C John 
KPMG, Tax Card Kosovo 2013. https://www.kpmg.com/AL/en/IssuesAndInsights/Documents/2013-Tax-card-Kosovo-EN-web.pdf Marx, Karl. The economics of Karl Marx, Analysis and Application (2002) fq 125

Paper. Deloitte, Drafti i ligjit i tatimit për të ardhurat, Përmbledhje e ndryshimeve.

Paper. Eurofast. Croatia Tax Card, http://www.eurofast.eu/global/phocadownload/Taxand2015/croatiataxcard2015.pdf

Paper. Politika Fiskale, Taksat dhe tatimet kryesore në sistemin tatimor Shqipëtar

Rabushka, Alvin. Taxation in colonial America.(2008). Princeton University Press

Agjencia Shqiptare e Zhvillimit të Investimeve, (AIDA)

Directorate of General of Taxes, Data base 2015.

Law nr.8438 on 28.12.1998 "Income taxes"changed with the Directive of the Ministry of Finances nr. 5 on 30.01.2006 "Income taxes" Ministry of Finance, Albania

UNCTAD, World Investment Report 2014, Bank of Albania

UNCTAD, World Investment Report 2015, Bank of Albania 